\title{
Development of Carbazole Derivatives Compounds against Candida albicans: Candidates to Prevent Hyphal Formation via the Ras1-MAPK Pathway
}

\author{
Young-Kwang Park ${ }^{1}{ }^{\oplus}$, Jisoo Shin ${ }^{2}$, Hee-Yoon Lee ${ }^{2}{ }^{\circledR}$, Hag-Dong Kim ${ }^{3}$ and Joon Kim ${ }^{1,3, *}$ \\ 1 Laboratory of Biochemistry, Division of Life Sciences, Korea University, Seoul 02841, Korea; \\ 01091210524@korea.ac.kr \\ 2 Department of Chemistry, KAIST, Daejeon 34141, Korea; lucky5624@kaist.ac.kr (J.S.); \\ leehy@kaist.ac.kr (H.-Y.L.) \\ 3 HAEL, TechnoComplex Building 603-3, Korea University, Seoul 02841, Korea; kste99@yahoo.co.kr \\ * Correspondence: joonkim@korea.ac.kr
}

check for

updates

Citation: Park, Y.-K.; Shin, J.; Lee, H.-Y.; Kim, H.-D.; Kim, J.

Development of Carbazole

Derivatives Compounds against

Candida albicans: Candidates to

Prevent Hyphal Formation via the

Ras1-MAPK Pathway. J. Fungi 2021, 7,

688. https://doi.org/10.3390/

jof7090688

Academic Editor: Praveen Juvvadi

Received: 7 July 2021

Accepted: 24 August 2021

Published: 25 August 2021

Publisher's Note: MDPI stays neutral with regard to jurisdictional claims in published maps and institutional affiliations.

Copyright: (c) 2021 by the authors. Licensee MDPI, Basel, Switzerland. This article is an open access article distributed under the terms and conditions of the Creative Commons Attribution (CC BY) license (https:// creativecommons.org/licenses/by/ $4.0 /)$.

\begin{abstract}
Morphogenesis contributes to the virulence of the opportunistic human fungal pathogen Candida albicans. Ras1-MAPK pathways play a critical role in the virulence of $C$. albicans by regulating cell growth, morphogenesis, and biofilm formation. Ume6 acts as a transcription factor, and Nrg1 is a transcriptional repressor for the expression of hyphal-specific genes in morphogenesis. Azoles or echinocandin drugs have been extensively prescribed for C. albicans infections, which has led to the development of drug-resistant strains. Therefore, it is necessary to develop new molecules to effectively treat fungal infections. Here, we showed that Molecule B and Molecule C, which contained a carbazole structure, attenuated the pathogenicity of $C$. albicans through inhibition of the Ras1/MAPK pathway. We found that Molecule B and Molecule C inhibit morphogenesis through repressing protein and RNA levels of Ras/MAPK-related genes, including UME6 and NRG1. Furthermore, we determined the antifungal effects of Molecule B and Molecule $C$ in vivo using a candidiasis murine model. We anticipate our findings are that Molecule B and Molecule C, which inhibits the Ras1/MAPK pathway, are promising compounds for the development of new antifungal agents for the treatment of systemic candidiasis and possibly for other fungal diseases.
\end{abstract}

Keywords: fungi; morphogenesis; Candida albicans; pathogenicity; Ras1; MAPK pathway; drug resistance; biofilm formation; candidiasis; drug development

\section{Introduction}

Candida albicans is a commensal fungal pathogen that causes opportunistic infections in humans. Life-threatening systemic fungal infections occur mainly in immunocompetent and immunocompromised humans, such as patients with AIDS, immunosuppressanttreated organ transplant patients, and recently patients with COVID-19 [1-3]. Candida infection has shown an increasing prevalence and severity with an increase in AIDS prevalence, chemotherapy, and organ transplantation. Candidemia accounts for approximately $9 \%$ of nosocomial bloodstream infections, and when C. albicans invades the internal organs, it can cause severe candidiasis with a mortality rate of approximately $40 \%$.

Morphogenesis is critical for the pathogenicity of $C$. albicans [4,5]. It has two main forms: yeast and hyphal. The dimorphism that allows the ability to switch between yeast and hyphal growth forms is essential for pathogenicity. The yeast form is required for adhesion and colonization of the epithelial cells of the host, while the hyphal form is required for the penetration and invasion of the endothelial cells of the host [6]. Morphogenesis has various environmental cues, such as nutrient limitation, alkaline $\mathrm{pH}$, quorum sensing molecules, serum, elevated temperature, and elevated $\mathrm{CO}_{2}[7,8]$. For in vitro experiments, serum exposed to elevated temperature $\left(37^{\circ} \mathrm{C}\right)$ was used for hyphal formation [9]. Therefore, novel drugs that have the ability to inhibit the morphogenesis of $C$. albicans must 
be screened. In C. albicans, MAPK and Ras/PKA-dependent pathways regulate nutrient sensing and acquisition, stress response, and pathogenesis, as well as play a potent role in hyphal formation $[10,11]$. The small GTPase Ras1 in this fungus affects both pathways and acts as a switch for hyphal formation signals, such as serum, elevated temperature, and nutrient limitation [11]. As one of the MAPKs, Cek1 has a role in biofilm formation and filamentous growth in C. albicans, while another MAPK, Mkc1, has a function in the formation and maintenance of cell wall structure [10]. CaUme6 is a transcription factor that maintains filamentous growth in hyphal formation and upregulates hyphal-specific genes (HSGs) encoding hyphal cell-related components, such as Hwp1, Als3, and Ece1 proteins [12]. The transcriptional repressor Nrg1 works with Ume6 as a negative feedback loop to control the expression of HSGs in hyphal growth environmental signals $[13,14]$.

Fluconazole, an azole drug typically used as an antifungal agent, targets the enzyme essential for cell wall ergosterol biosynthesis. Other antifungal drugs, such as amphotericin B (polyene) and echinocandin target the fungal membrane and cell wall synthesis, respectively. In the ergosterol biosynthesis pathway, azoles inhibit ERG11, which encodes $14 \alpha$-demethylase (cytochrome P450 enzyme lanosterol demethylase) [15]. The azole-resistant $C$. albicans strains have been isolated from patients prescribed chemotherapy drugs. The azole-resistant $C$. albicans strains have some features, such as point mutations and the overexpression of ERG11, azole target, and overexpression of drug efflux pumps Cdr1 and Mdr1. To effectively treat infections caused by these drug-resistant $C$. albicans strains, the necessity of new antifungal drugs that have different targets from those of the commonly used drugs is emphasized.

Carbazole derivatives, which are widely used because of their biological activity, are receiving increasing attention in antitumor, antibacterial, and antifungal studies [16-18]. They have been shown to exhibit antifungal activity against a variety of fungi, including C. albicans, but the exact underlying mechanism has not been studied. In our previous study, we investigated the correlation between vacuolar activity and pathogenicity in C. albicans through deletion of V-ATPase subunits vma4 and vma10 [19], and the results suggested that targeting vacuoles with novel fungicidal agents would be beneficial. In this study, 31 compounds containing a carbazole structure were synthesized as a result of preparing an analog, such as bafilomycin A1 with vacuole inhibitory activity. Molecule B and Molecule $C$ were selected through the screening and evaluation of 31 carbazole derivatives. Both showed excellent efficacy in inhibiting morphogenesis and pathogenicity but did not significantly affect the vacuolar activity in C. albicans. Here, we describe Molecule B and Molecule C, which inhibit the Ras1/MAPK pathway to prevent hyphal morphogenesis and consequently attenuate the pathogenicity in C. albicans. Overall, this study focused on elucidating the mechanism of action and evaluating the antifungal activity using both in vitro and in vivo models to confirm the potential of Molecule B and Molecule $\mathrm{C}$ as novel antifungal drugs for Candida infection.

\section{Materials and Methods}

\subsection{Strains, Culture Media, and Chemicals}

The $C$. albicans strains, including fluconazole and caspofungin-resistant strains, primers, and 31 carbazole derivatives used in this study are listed in Table 1, Supplementary Table S1 and Figure S4, respectively. To generate the Ume6-myc and Nrg1-myc strains, PCR-based gene disruption was performed using HIS1 and 9myc-NAT1 cassettes. The primers for amplification of the cassettes (HIS1 and 9myc-NAT1) are listed in Supplementary Table S1. To generate the UME6-9myc and NRG1-9myc strains, pFA6a-9myc-NAT1 was used for UME69myc-NAT1 and NRG1-9myc-NAT1 cassettes. These DNA cassettes were transformed into the ume6::HIS1/UME6 and nrg1::HIS1/NRG1 strains. To confirm strain generation, genomic DNA was isolated, and PCR and western blotting were performed with specific primers and antibodies.

Saccharomyces cerevisiae (Figure S1b) and C. albicans cells were cultivated at $30{ }^{\circ} \mathrm{C}$ in YPD medium (1\% yeast extract, $2 \%$ peptone, and $2 \%$ dextrose), as previously de- 
scribed [20,21]. For the induction of hyphal morphogenesis in C. albicans, incubation was performed in YPD medium containing $10 \%$ fetal bovine serum (FBS) at $37^{\circ} \mathrm{C}$ with shaking. A complete synthetic medium $(0.76 \%$ yeast nitrogen base without amino acids and $2 \%$ dextrose) supplemented with the appropriate auxotrophic requirements and uridine $(50 \mu \mathrm{g} / \mathrm{mL})$, was used to select positive transformants. RPMI 1640 (pH 7.0) with $0.165 \mathrm{M}$ MOPS liquid medium was used for susceptibility determination according to the Clinical and Laboratory Standards Institute (CLSI) document M27-A3 [22].

Caspofungin and fluconazole were dissolved in DMSO to a final concentration of $20 \mathrm{mg} / \mathrm{mL}$. All stock solutions of 31 carbazole derivatives were dissolved in sterile distilled water or methanol to a final concentration of $20 \mathrm{mg} / \mathrm{mL}$. All stock solutions were stored at $-20{ }^{\circ} \mathrm{C}$ until use.

Table 1. Candida albicans strains used in this study.

\begin{tabular}{ccc}
\hline Strain & Relevant Genotype & Source \\
\hline SC5314 & Clinical isolate from the London Mycological Reference Laboratory & {$[23]$} \\
BWP17 & ura3::imm434/ura3::imm434 his1::hisG/his1::hisG arg4::hisG/arg4::hisG & {$[24]$} \\
Ume6-myc & As BWP17 except for ume6::HIS1/UME6-9myc-NAT1 & In this study \\
Nrg1-myc & As BWP17 except for nrg1::HIS1/NRG1-9myc-NAT1 & In this study \\
tetO-UME6 & As BWP17 except for ADH1/adh1::Ptet-UME6 & In this study \\
$12-99$ & Fluconazole resistant strain & {$[25]$} \\
89 & Caspofungin resistant strain & {$[26]$} \\
177 & Caspofungin resistant strain & {$[26]$} \\
\hline
\end{tabular}

\subsection{Antifungal Susceptibility Test}

The minimum inhibitory concentrations (MICs) of 31 carbazole derivatives against C. albicans were determined using the broth microdilution method as described in the CLSI guidelines [22]. The tests were performed in 96-well flat-bottomed microtiter plates. The final concentration of the cell suspension in the RPMI 1640 medium was $2 \times 10^{4}$ C. albicans SC5314 cells $/ \mathrm{mL}$, and the final concentration of the carbazole derivatives ranged between 0.125 and $64 \mu \mathrm{g} / \mathrm{mL}$. All the wells were filled with RPMI 1640 to a final volume of $200 \mu \mathrm{L}$. The plates were incubated at $37^{\circ} \mathrm{C}$ for $24 \mathrm{~h}$. Growth inhibition was determined by measuring the optical density at $595 \mathrm{~nm}$ using a microplate reader. The MIC was defined as the lowest concentration of carbazole derivatives that inhibited the growth of cells by $95 \%$ compared to the control.

\subsection{Hyphae Formation}

YPD medium containing $10 \%$ FBS at $37^{\circ} \mathrm{C}$ was used to test the effect of Molecule B and Molecule C on hyphal formation. C. albicans SC5314 $\left(2 \times 10^{6}\right.$ cells $\left./ \mathrm{mL}\right)$ was inoculated in hyphal formation-inducing media containing Molecule B and Molecule $\mathrm{C}$ at MICs and incubated at $37^{\circ} \mathrm{C}$ with shaking for $2 \mathrm{~h}$. The morphology of the cells was photographed using a Zeiss Observer.Z1 (Carl Zeiss, Jena, Germany).

\subsection{Determination of the Minimum Inhibitory Concentrations of C. albicans Biofilm Formation}

Inhibition of biofilm formation was investigated by seeding $2 \times 10^{4}$ C. albicans SC5314 cells $/ \mathrm{mL}$ in a $200 \mu \mathrm{L}$ cell suspension into 96-well flat-bottom microtiter plates, adding Molecule $\mathrm{B}$ and Molecule $\mathrm{C}$ to final concentrations ranging between 0.125 and $64 \mu \mathrm{g} / \mathrm{mL}$, and incubating at $37^{\circ} \mathrm{C}$ for $24 \mathrm{~h}$. Each well was washed with $200 \mu \mathrm{L}$ of PBS three times to remove planktonic cells. A metabolic assay based on the reduction of XTT (sodium 3'-[1-(phenylaminocarbonyl)-3,4-tetrazolium]-bis (4-methoxy6-nitro) benzene sulfonic acid hydrate) was performed to determine the biofilm formation inhibitory concentrations. It referred to the lowest concentrations, where there was a $95 \%$ reduction in the XTTcolorimetric readings compared with the control. Colorimetric absorbance was measured at $495 \mathrm{~nm}$ using a microtiter plate reader. 


\subsection{Cell Cytotoxicity Test}

The cytotoxicity of the carbazole derivatives was determined in HeLa cells. HeLa cells were maintained as previously described $[27,28]$ in Dulbecco's modified Eagle's medium (DMEM, Invitrogen, Waltham, MA, USA) supplemented with 10\% FBS (Invitrogen, Waltham, MA, USA) and grown at $37^{\circ} \mathrm{C}$ in a humidified atmosphere of $5 \% \mathrm{CO}_{2}$. Viability was measured using the MTS assay. Each well was inoculated with $104 \mathrm{HeLa}$ cells and incubated at $37{ }^{\circ} \mathrm{C}$ for $24 \mathrm{~h}$ in 96-well flat-bottom tissue culture plates using DMEM containing $10 \%$ FBS. Carbazole derivatives were added at final concentrations ranging from 0.125 to $64 \mu \mathrm{g} / \mathrm{mL}$ and incubated at $37^{\circ} \mathrm{C}$ for $16 \mathrm{~h}$. The MTS solution with PMS was added, and the cells were incubated for $10 \mathrm{~min}$. The absorbance at $490 \mathrm{~nm}$ was measured using a microplate reader.

\subsection{Real-Time PCR}

Real-time PCR was conducted as described previously [27,29-31]. Overnight cultured C. albicans cells were diluted in fresh YPD for $2 \mathrm{~h}$ at $30^{\circ} \mathrm{C}$ to induce yeast growth. Overnight cultured C. albicans cells were diluted in fresh YPD supplemented with $10 \%$ FBS for $2 \mathrm{~h}$ at $37^{\circ} \mathrm{C}$ to induce hyphal formation in the absence or presence of Molecule B and Molecule C at the final MICs. Total RNA samples of yeast or hyphal-formed cells were isolated using the bead beater (MP FastPrep-24, cooled on ice for 3 min each time, 12 times for 15 s.) and TRIzol reagent method. Total RNA was measured using the Nanodrop 1000 Spectrophotometer (Thermo Scientific, Rockford, IL, USA). Total RNA was treated with RQ1 DNase (Promega, Madison, WI, USA) and was reverse transcribed into cDNAs using oligo-d (T) and M-MLV reverse transcriptase (Promega, Madison, WI, USA). The cDNA preparation was diluted by $1 / 20$ in Ultrapure distilled water (Invitrogen, Waltham, MA, USA) and stored at $-20^{\circ} \mathrm{C}$ until processing for real-time PCR. SensiFAST SYBR master mix (Meridian Bioscience, Cincinnati, OH, USA) was used to monitor the amplified products in real-time. Real-time PCR was performed with the specific primers listed in Supplementary Table S1 using the LightCycler 480 (Roche, Manheim, Germany). Relative levels of target gene expression were calculated and normalized to the expression of ACT1.

\subsection{Immunoblotting}

Western blotting was performed as described previously [20,31,32], with slight modification. Briefly, yeast or hyphal formed cells were harvested and washed with ice-cold PBS. To prepare whole cell lysates, the cells were lysed with ice-cold buffer comprised of $50 \mathrm{mM}$ Tris- $\mathrm{HCl}$ (pH 7.5), $150 \mathrm{mM} \mathrm{NaCl}, 5 \mathrm{mM}$ EDTA, $10 \%$ glycerol, $0.2 \%$ Nonidet P- $40,1 \mathrm{mM}$ dithiothreitol, protease inhibitors ( $1 \mathrm{mM}$ phenylmethylsulfonyl fluoride and $1 \mu \mathrm{g} / \mathrm{mL}$ aprotinin, pepstatin $\mathrm{A}$, and leupeptin), $0.1 \mathrm{mM}$ sodium orthovanadate, $20 \mu \mathrm{M}$ sodium glycerophosphate, $20 \mu \mathrm{M}$ para-nitrophenyl phosphate, and $20 \mu \mathrm{M}$ sodium fluoride. The cells were lysed using glass beads (Sigma-Aldrich, Burlington, MA, USA) in a Fast prep-24 device (MP Biomedicals, Santa Ana, CA, USA). The proteins were resolved on 10-12\% SDS-PAGE and analyzed using immunoblotting on PVDF membranes according to standard procedures. For the detection of Ras1, Ume6-myc, Nrg1-myc, Cek1, Mkc1, phosphorylated Cek1, and phosphorylated Mkc1, the primary antibody (1:3000 dilution for Ras1 (05-516 Merck, Darmstadt, Germany) and 1:1000 dilution for c-Myc (c-Myc (9E10) Santa Cruz Biotechnology, Dallas, TX, USA), 1:1000 dilution for Cek1/Mkc1 (9102S Cell Signaling Technology, Danvers, MA, USA), and 1:1500 dilution for phospho-Cek1/phosphor-Mkc1 (4307T Cell Signaling Technology, Danvers, MA, USA) were used. For the loading control, $\beta$-actin antibody (ab8224 Abcam, Cambridge, UK) was used at 1:1000 dilution. The membranes were blocked using Tris-buffered saline containing $0.1 \%$ Tween, containing $5 \%$ skim milk. The BM Chemiluminescence Western Blotting Substrate kit was used to develop the blot.

\subsection{Antifungal Activity Test in the Murine Candidiasis Model}

Overnight-cultured C. albicans strains were pelleted and washed three times with $1 \mathrm{~mL}$ of sterile PBS. Next, $1.0 \times 10^{6}$ C. albicans SC5314 cells were resuspended in $200 \mu \mathrm{L}$ 
PBS and injected into 5-week-old BALB/c (female) mice via lateral tail veins. After the establishment of the murine model, mice ( $n=5$ /group) were treated by tail vein injection with Molecule B and Molecule C ( 8 or $16 \mathrm{mg} / \mathrm{kg}$ ) or PBS every day from the second day. To investigate the voluntary intake effect, the mice were treated with Molecule B and Molecule $\mathrm{C}(8$ or $16 \mu \mathrm{g} / \mathrm{mL})$ or normal water every day. The dead mice were dissected, the kidneys were harvested, weighed, washed with PBS, chopped, spread on YPD plates, and incubated at $30{ }^{\circ} \mathrm{C}$ for 2 days, then the CFUs were counted to analyze the fungal infection burden. The mice were monitored for 1 month, and Kaplan-Meier survival curves were plotted.

\subsection{Ethics Statement}

This study was performed in accordance with the guidelines of the Institutional Animal Care and Use Committee of Korea University. The protocol and experiments were approved by the Institutional Animal Care and Use Committee of Korea University. The permit number is KUIACUC-2019-0061. All mice used in the experiments were euthanized with minimal suffering.

\section{Results}

\subsection{Identification of Carbazole Derivatives That Inhibit the Growth of Candida Albicans}

To screen for carbazole derivatives that have growth inhibitory effects on C. albicans, the MICs of 31 carbazole derivatives were investigated. The MIC of Molecule B was $8 \mu \mathrm{g} / \mathrm{mL}$, which showed the best effect among the 31 carbazole derivatives (Figures 1a and S1a, and Table 2). In addition, Molecule B was noncytotoxic in mammalian cells up to a concentration of $16 \mu \mathrm{g} / \mathrm{mL}$ (Figures $1 \mathrm{~b}$ and S1c). The noncytotoxic concentration of Molecule $\mathrm{B}, 16 \mu \mathrm{g} / \mathrm{mL}$, corresponds to twice its MIC, $8 \mu \mathrm{g} / \mathrm{mL}$, so it was considered suitable for the experiment, and Molecule B was selected as one of the leading carbazole derivatives. Carbazole derivatives with a MIC of $16 \mu \mathrm{g} / \mathrm{mL}$ were Molecule C, Molecule C-M5, Molecule C-M6, Molecule C-M10, Molecule F, and Molecule N (Figure 1a). However, Molecule C-M5, Molecule C-M6, Molecule F, and Molecule N were excluded because their MICs showed cytotoxicity in mammalian cells (Figure 1b). Molecule C and Molecule C-M10 were noncytotoxic to mammalian cells even when their concentration was $32 \mu \mathrm{g} / \mathrm{mL}$, which corresponds to a double MIC, $16 \mu \mathrm{g} / \mathrm{mL}$ (Figures $1 \mathrm{~b}$ and S1c). Of the two, Molecule C was water-soluble; thus, it was considered advantageous for new drug development. Therefore, Molecule B and Molecule C were selected as the two leading carbazole derivatives in this study. Surprisingly, the MICs of Molecule B and Molecule C for fluconazole- and caspofungin-resistant $C$. albicans strains showed the same MIC as that of the reference strain (Table 2). Molecule B and Molecule C both showed the same MICs $(4 \mu \mathrm{g} / \mathrm{mL})$ in BY4741, a wild-type strain of $S$. cerevisiae (Figure S1b). These results suggest that Molecule $B$ and Molecule $C$ have growth inhibitory activity against $C$. albicans, including strains that are resistant to existing drugs.

Table 2. MICs of Molecule B and Molecule C in C. albicans.

\begin{tabular}{|c|c|c|c|c|}
\hline & Fluconazole & Caspofungin & Molecule B & Molecule C \\
\hline SC5314 ${ }^{a}$ & 1 & 1 & 8 & 16 \\
\hline $12-99 \mathrm{~b}$ & $>128$ & 1 & 8 & 16 \\
\hline $89^{c}$ & $>64$ & 4 & 8 & 16 \\
\hline $177^{c}$ & 1 & 4 & 8 & 16 \\
\hline
\end{tabular}

All units indicated are $\mu \mathrm{g} / \mathrm{mL} .{ }^{\text {a }}$ Candida albicans reference strain. ${ }^{\mathrm{b}}$ Fluconazole resistant Candida albicans strain [25]. ${ }^{\mathrm{C}}$ Caspofungin resistant Candida albicans strain [26]. 
a

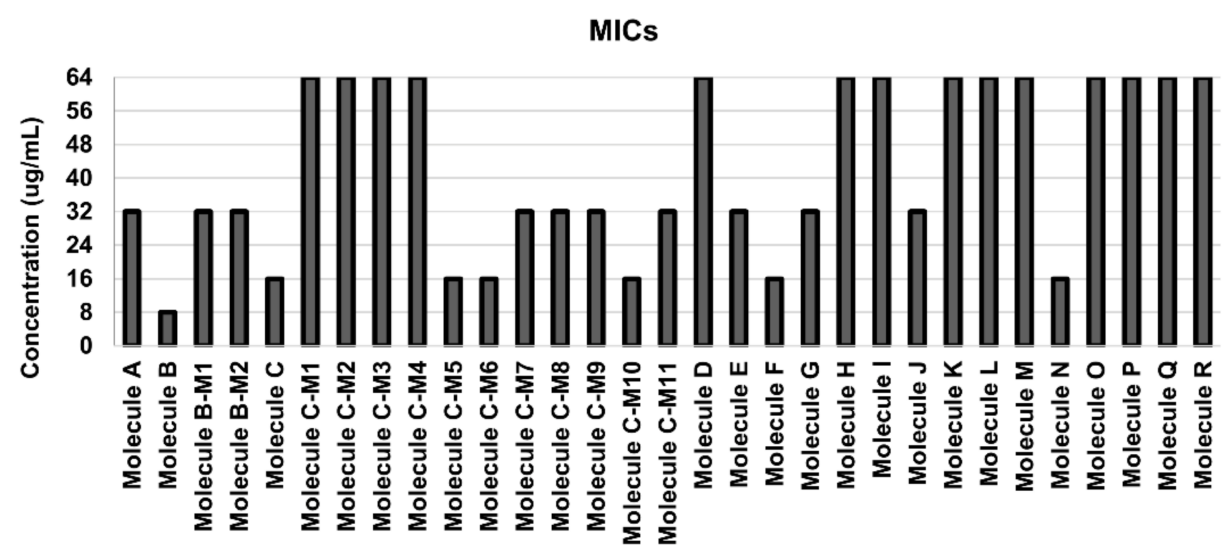

b

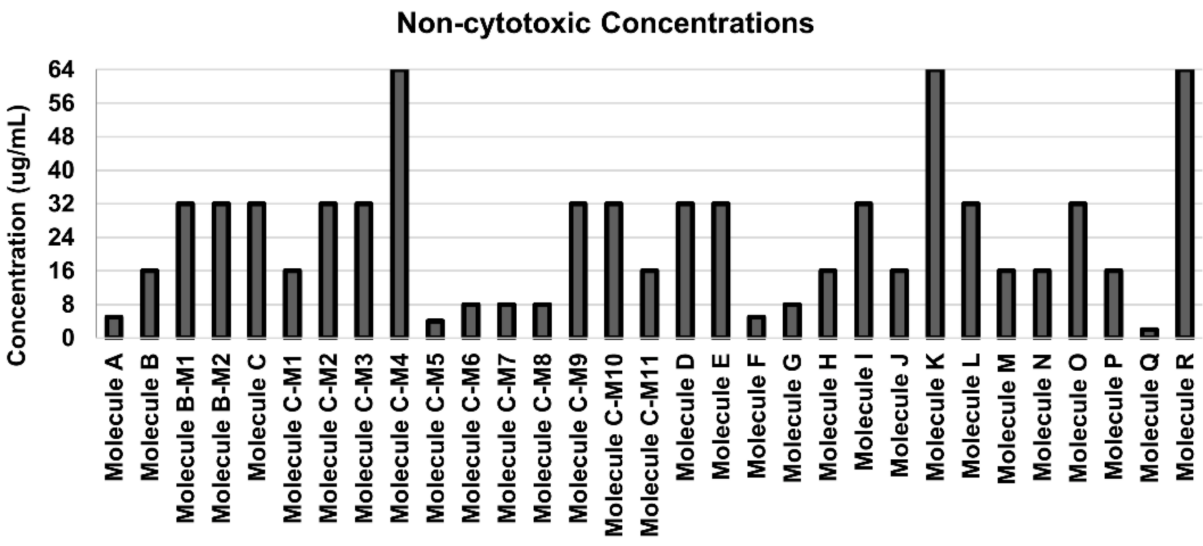

Figure 1. Cytotoxicity of carbazole derivatives in C. albicans and mammalian cells. (a) Minimum inhibitory concentrations (MICs) of 31 carbazole derivatives. MICs were defined as the lowest concentration of carbazole derivatives that inhibited the growth of the C. albicans SC5314 cells by 95\% compared with the control. (b) Analysis of the cytotoxicity of carbazole derivatives on HeLa cells. The cytotoxicity was determined using the MTS assay. The noncytotoxic concentrations were defined as the highest concentration of carbazole derivatives that inhibited the growth of the cells by $5 \%$ compared with the control. The absorbance at $490 \mathrm{~nm}$ was measured with a microtiter plate reader. Each experiment was conducted in triplicate.

\subsection{Inhibitory Effects of Molecule B and Molecule C on Morphogenesis and Biofilm Formation in Candida Albicans}

In the hyphae inducing condition, hyphae were formed in $96 \%$ of cells in the control group; however, when treated with Molecule B and Molecule C, hyphae were formed in only $3 \%$ and $6 \%$ of cells, respectively (Figure $2 a$ ). The microscopy images showed the inhibitory effect of Molecule B and Molecule $C$ on morphogenesis (Figure $2 b$ ). Biofilm can attach to host organs or medical devices and plays an important role in adhesion to and penetration of host tissues $[33,34]$. It was observed that biofilm formation was also inhibited by Molecule $B$ and Molecule $C$ at a minimum concentration of $1 \mu \mathrm{g} / \mathrm{mL}$ (Figure 2c). These results suggested that Molecule $B$ and Molecule $C$ can significantly inhibit pathogenicity by inhibiting the hyphal morphogenesis of $C$. albicans. 
a

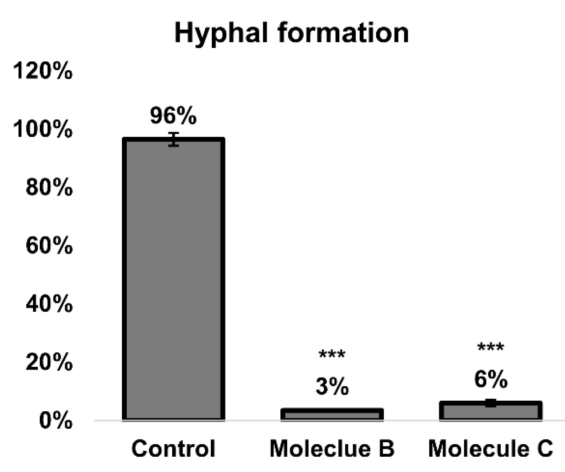

b

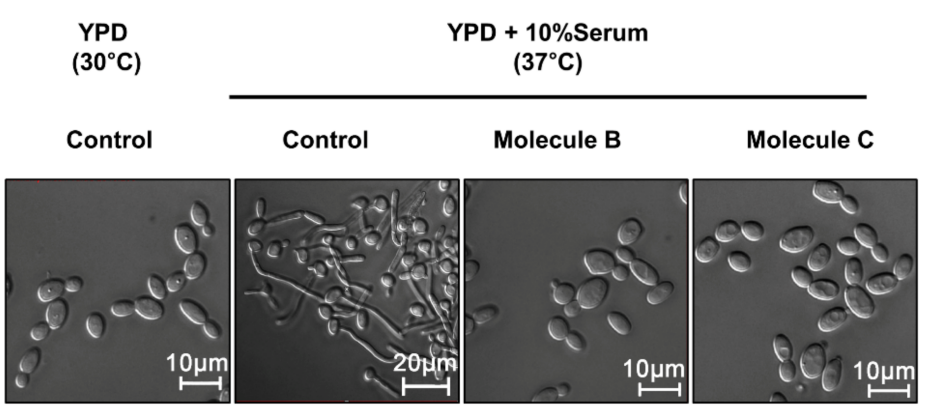

c

\section{Biofilm formation}

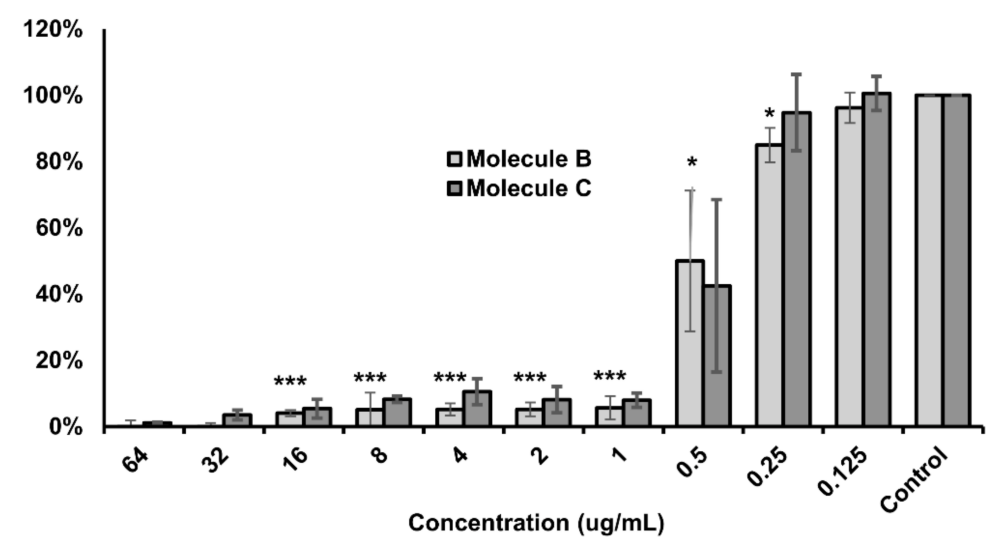

Figure 2. Inhibitory effect of Molecule B and Molecule $C$ on morphogenesis and biofilm formation in $C$. albicans. (a) The inhibitory effects of Molecule B and Molecule $\mathrm{C}$ on the hyphal formation of $C$. albicans SC5314. To induce hyphae formation, YPD with 10\% FBS was used and incubated for $2 \mathrm{~h}$ at $37^{\circ} \mathrm{C}$. Molecule B was treated at $8 \mu \mathrm{g} / \mathrm{mL}$, and Molecule $C$ was treated at $16 \mu \mathrm{g} / \mathrm{mL}$. (b) A minimum of 300 C. albicans SC5314 cells were counted for each treatment to evaluate the morphogenesis inhibitory effect as a percentage. To observe the morphology change using a microscope, Molecule B and Molecule C were administered at each MIC. Scale bars represent $10 \mu \mathrm{m}$ (yeast form) and $20 \mu \mathrm{m}$ (hyphae). (c) The inhibitory effect of Molecule B and Molecule C on C. albicans biofilm formation. Biofilms were formed by inoculation $2 \times 10^{4}$ C. albicans SC5314 cells $/ \mathrm{mL}$ in $200 \mu \mathrm{L}$ cell suspension into 96-well flat-bottomed microtiter plates adding Molecule B and Molecule $C$ to final concentrations ranging between 0.125 and $64 \mu \mathrm{g} / \mathrm{mL}$ and incubating at $37^{\circ} \mathrm{C}$ for $24 \mathrm{~h}$. A metabolic assay based on the reduction of XTT was performed to determine the biofilm formation inhibitory concentrations. Colorimetric absorbance was measured at $495 \mathrm{~nm}$ in a microtiter plate reader. Each experiment was conducted in triplicate. The data represent the mean and standard deviation of three independent experiments. ${ }^{*} p<0.05,{ }^{* * *} p<0.001$ ( $t$-test). 


\subsection{Virulence Diminishes in the Candidiasis Murine Model Treated with Molecule B and Molecule $C$ via Oral Intake and Vein Injection}

In addition to in vitro investigations, we conducted studies using a candidiasis mouse model to investigate whether Molecule $B$ and Molecule $C$ have antifungal properties against $C$. albicans in vivo. Both groups of control candidiasis mice died after 9 or 8 days (Figure 3a,c). On the other hand, the mice treated with Molecule B and Molecule C by tail vein injection showed higher survival rates (Figure 3a). The degrees of Candida infection of the kidneys, which are a major target of $C$. albicans [35], were also markedly lower in the groups administered Molecule $B$ and Molecule $C$ by tail vein injection (Figure $3 b$ ) than the control group. It was also observed that the survival rates of the mouse groups fed water containing Molecule $\mathrm{B}$ and Molecule $\mathrm{C}$ for autonomous intake were also very high (Figure 3c). In addition, the mice that drank water containing Molecule B and Molecule $C$ showed a very low infection rate compared to the control group (Figure 3d). Through these results, it was confirmed that Molecule B and Molecule C were effective in inhibiting morphogenesis in vitro as well as in inhibiting pathogenicity in vivo.

a

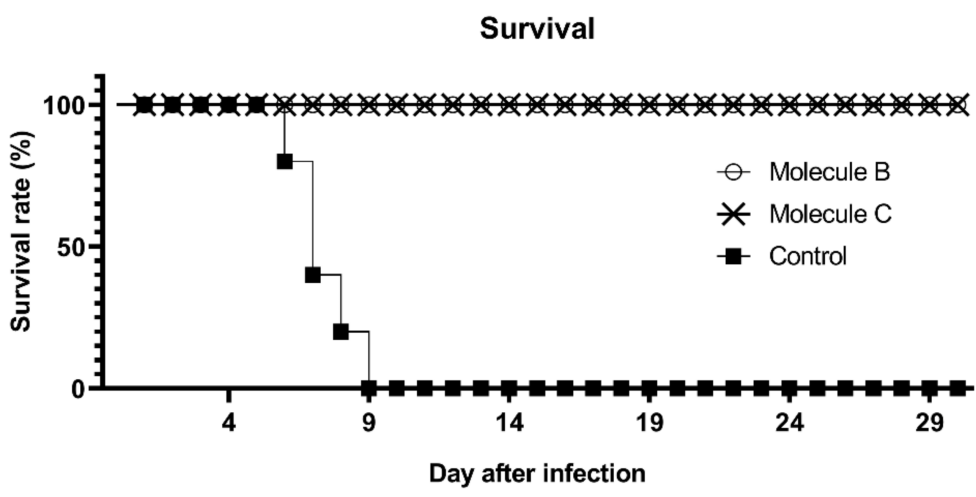

C

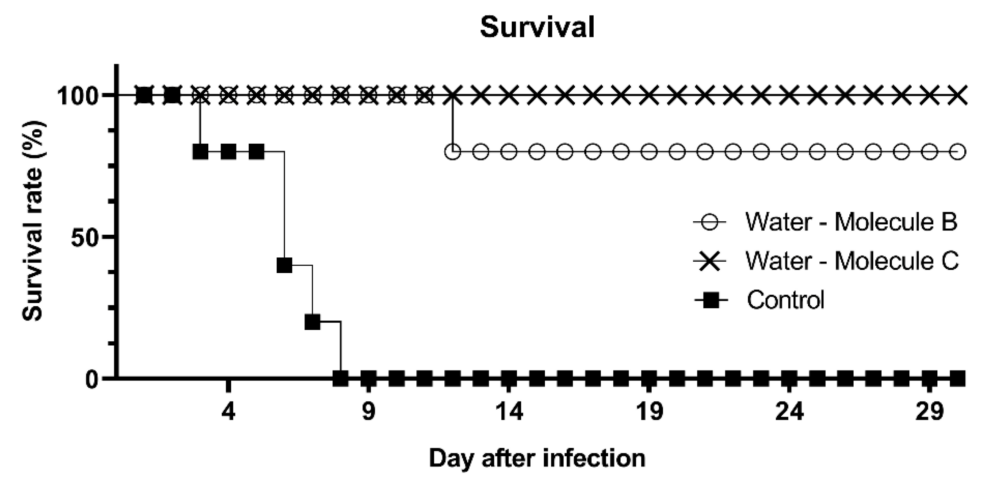

b

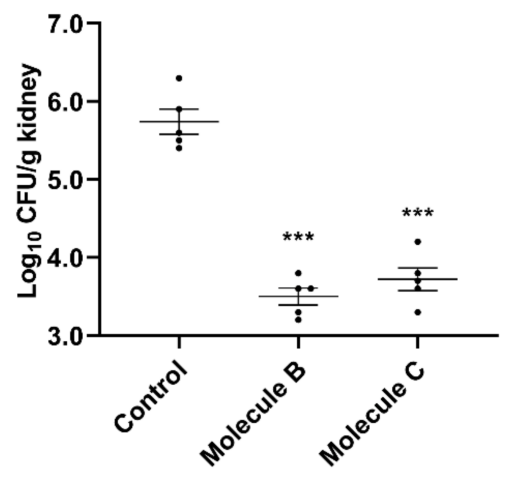

d

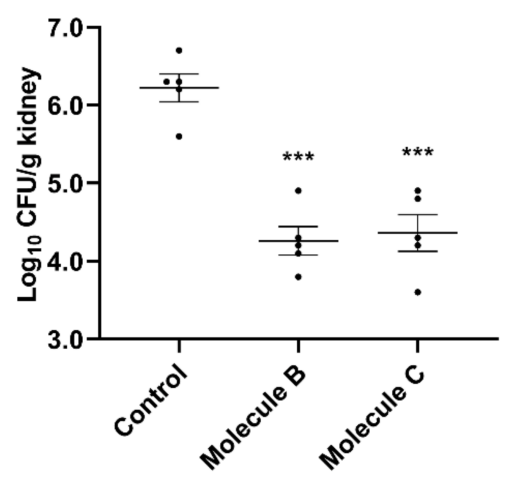

Figure 3. Attenuation of C. albicans pathogenicity by Molecule B and Molecule C treatment in the candidiasis murine model. The candidiasis mouse model was established by the inoculation of $5 \times 10^{6}$ cells of $C$. albicans SC5314 through tail vein injection. (a) From the day after C. albicans infection to the 30th day, Molecule B and Molecule C were injected at 8 and $16 \mathrm{mg} / \mathrm{kg}$, respectively, via tail vein injection, and the survival rate was measured every day. (b) The dead mice were dissected, the kidneys were harvested, weighed, washed with PBS, chopped, spread on YPD plates, and incubated at $30{ }^{\circ} \mathrm{C}$ for 2 days, and then the CFUs were counted to analyze the burden of fungal infection. Each $\log _{10} \mathrm{CFU}$ value is indicated by a dot, and the mean and standard error values are indicated by a horizontal line. (c) For 1 month from the day after C. albicans infection, Molecule B and Molecule C were diluted to 8 and $16 \mathrm{mg} / \mathrm{L}$, respectively, in the drinking water of the mice, and the survival rate was measured every day after allowing the mice to ingest autonomously. (d) The dead mice were dissected, the kidneys were harvested, weighed, washed with PBS, chopped, spread on YPD plates, and incubated at $30^{\circ} \mathrm{C}$ for 2 days, and the CFUs were counted to analyze the fungal infection burden. Each Log 10 CFU value is indicated by a dot, and the mean and standard error values are indicated by a horizontal line. ${ }^{* * *} p<0.001$ ( $t$-test). 
3.4. Molecule B and Molecule C Inhibit the Morphogenesis of C. albicans by Regulating the Protein Levels of Nrg1 and Ume6

We investigated whether Molecule B and Molecule C decreased the level of HSGs associated with filamentous and invasive growth $[13,36]$ in C. albicans. In C. albicans cells treated with Molecule B and Molecule C, the expression of ECE1 encoding Ece1, a cytolytic peptide toxin essential for mucosal infection [37], was inhibited (Figure 4a). The expression of $A L S 3$, encoding Als3, which plays an important role in cell adhesion and host surface adhesion [36,38], was also reduced (Figure 4a). In addition, the expression of HWP1, a cell-surface adhesion function in the hyphal cell wall $[39,40]$, was markedly reduced (Figure 4a). Furthermore, it was confirmed that the expression of HGC1, which encodes a hypha-specific G1 cyclin-related protein essential for hyphal morphogenesis [41], was reduced (Figure 4a). Moreover, we continued to investigate two proteins, Nrg1 [13,14] and Ume6 [12], which act as negative feedback regulators at the transcriptional level under filament growth conditions, affecting the expression levels of HSGs. The Nrg1 protein level of $C$. albicans cells treated with Molecule B and Molecule $C$ from 0 to $2 \mathrm{~h}$ was higher (Figure $4 \mathrm{~b}$ ) than the control. In addition, it was confirmed that the transcriptional level of NRG1 was significantly increased in C. albicans cells treated with Molecule B and Molecule C (Figure 4c). On the other hand, Ume6 protein, which showed an increase with time in hyphae-induced C. albicans cells, was not detected at all time points in C. albicans cells treated with Molecule B and Molecule C (Figure 4d). In addition, it was observed that the mRNA expression level of UME6 was significantly decreased in both the groups treated with Molecule B and Molecule C (Figure 4e).

We established a strain called tetO-UME6, in which one allele of UME6 was driven by a tetracycline-regulated promoter [42] to investigate whether the hyphal formation of C. albicans under constitutive UME6 expression was inhibited by Molecule B and Molecule $\mathrm{C}$ treatment. Molecule B and Molecule C treatment under constitutive expression of UME6 did not appear to be able to prevent the hyphal formation in C. albicans through direct Ume6 regulation (Figure S2). This result suggested that Molecule B and Molecule C treatments indirectly regulated the level of Ume6, which plays an important role in morphogenesis, thereby inhibiting C. albicans pathogenicity through the regulation of HSGs.

\subsection{Molecule B and Molecule C Regulate the Ras1 and MAPK Pathways}

We continued to investigate Ras signaling, which mediates hyphal growth induction in response to various environmental signals in C. albicans [7], to identify the upstream signaling pathway of Ume6. It was confirmed that RAS1 mRNA expression was significantly inhibited in C. albicans cells treated with Molecule B and Molecule C (Figure 5a). It was also shown that the protein expression levels of Ras1 were significantly reduced in C. albicans cells treated with Molecule B and Molecule C (Figure 5b). To investigate the MAPK signaling pathway involved in the hyphal formation of C. albicans [43], mRNA and protein levels of MKC1 and CEK1 were investigated. The mRNA expression levels of CEK1 and $M K C 1$ were decreased in C. albicans cells treated with Molecule B and Molecule C (Figure 5c,d). The protein levels of Cek1 and Mkc1 in C. albicans cells treated with Molecule $\mathrm{B}$ and Molecule $\mathrm{C}$ were not significantly different (Figure 5e). There was no difference in the change in the level of P-MKc1, an activated form of Mkc1 (Figure 5e). However, it was confirmed that the level of P-Cek1 was significantly reduced in C. albicans cells treated with Molecule B and Molecule C (Figure 5e). These results suggest that Ras1 is the key switch responsible for the antifungal effect of Molecule B and Molecule C through the Cek1 cascade activity in the MAPK pathway, which is well-known to be associated with the morphological transition in C. albicans. 
a

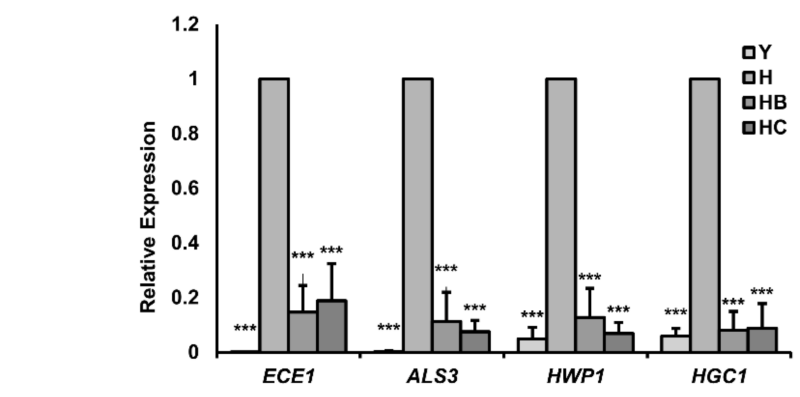

b

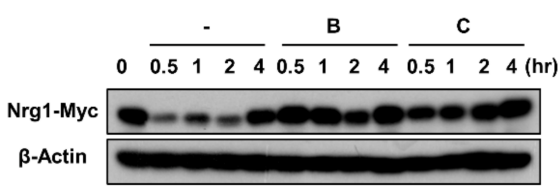

d

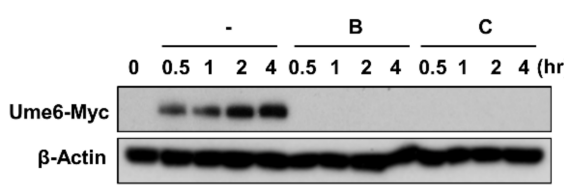

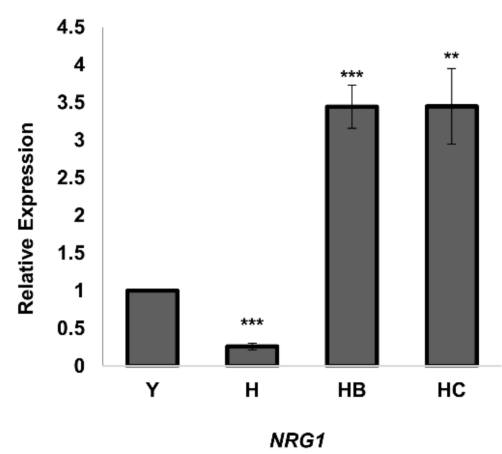

e

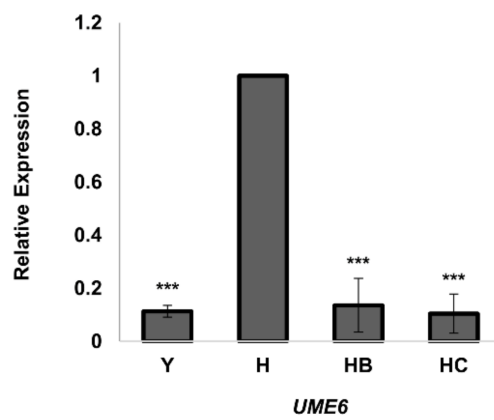

Figure 4. Effects of Molecule B and Molecule C on the expression of HSG, Ume6, and Nrg1 genes. (a) Realtime PCR for comparison of HSGs expression $2 \mathrm{~h}$ after hyphae induction. Used strain: BWP17. Y, yeast cells; $\mathrm{H}$, hyphae induced cells; $\mathrm{HB}$, hyphae induced cells with Molecule B treatment $(8 \mu \mathrm{g} / \mathrm{mL}) ; \mathrm{HC}$, hyphae induced cells with Molecule $\mathrm{C}$ treatment $(16 \mu \mathrm{g} / \mathrm{mL})$. (b) Changes in the protein levels of Nrg1 after inducing hyphal formation $(0-4 \mathrm{~h})$. Used strain: Nrg1-myc. B, hyphae induced cells with Molecule B treatment of $8 \mu \mathrm{g} / \mathrm{mL}$; C, hyphae induced cells with Molecule C treatment of $16 \mu \mathrm{g} / \mathrm{mL}$. (c) Realtime PCR for comparison of NRG1 expression $2 \mathrm{~h}$ after hyphae induction. Used strain: Nrg1-myc. Y, yeast cells; H, hyphae induced cells; HB, hyphae induced cells with Molecule B treatment $(8 \mu \mathrm{g} / \mathrm{mL}) ; \mathrm{HC}$, hyphae induced cells with Molecule $\mathrm{C}$ treatment $(16 \mu \mathrm{g} / \mathrm{mL})$. (d) Changes in protein levels of Ume6 after inducing hyphal formation (0-4 h). Used strain: Ume6-myc. B, hyphae induced cells with Molecule B treatment $(8 \mu \mathrm{g} / \mathrm{mL})$; C, hyphae induced cells with Molecule C treatment $(16 \mu \mathrm{g} / \mathrm{mL})$. (e) Realtime PCR for the comparison of UME6 expression $2 \mathrm{~h}$ after hyphal formation induction. Used strain: Ume6-myc. Y, yeast cell; $\mathrm{H}$, hyphae induced cells; HB, hyphae induced cells with Molecule B treatment $(8 \mu \mathrm{g} / \mathrm{mL}) ; \mathrm{HC}$, hyphae induced cells with Molecule $C$ treatment $(16 \mu \mathrm{g} / \mathrm{mL})$. Western blotting was performed with an anti-myc antibody to detect Nrg1-myc and Ume6-myc. In western blotting, $\beta$-actin was used as a loading control by detection using the anti- $\beta$-actin antibody. Each experiment was conducted in triplicate. The data represent the mean and standard deviation of three independent experiments. ${ }^{* *} p<0.01$, *** $p<0.001$ ( $t$-test). 


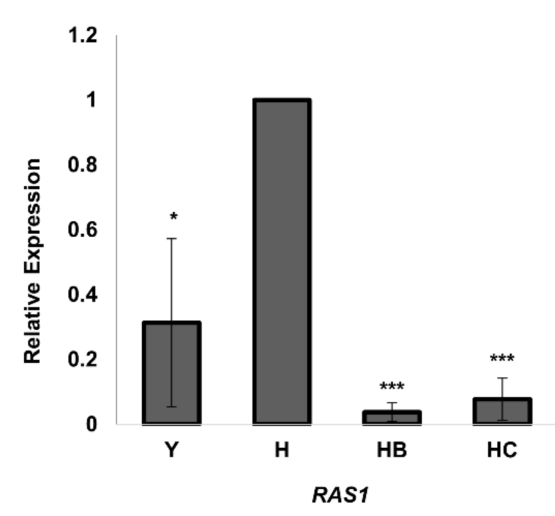

C

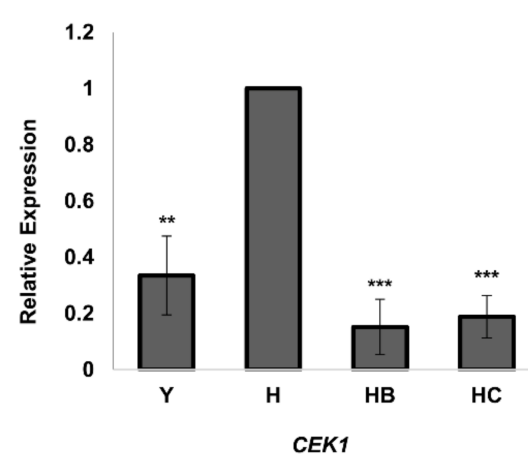

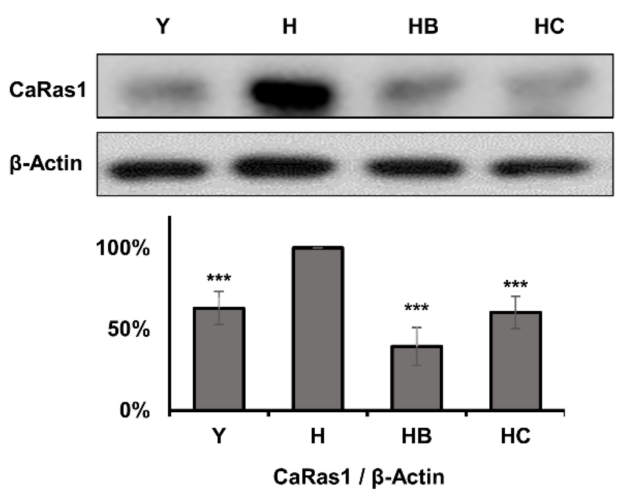

d

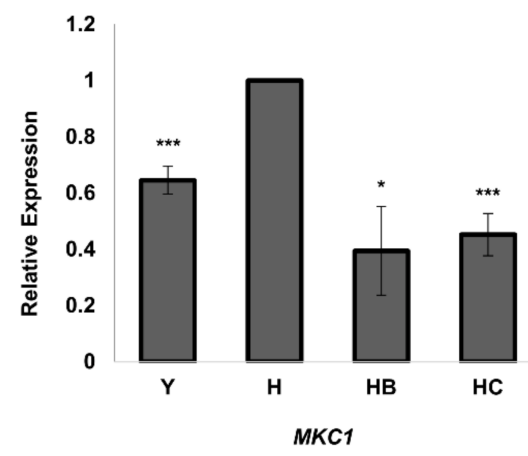

e

$\mathbf{Y}$

H

HB

HC

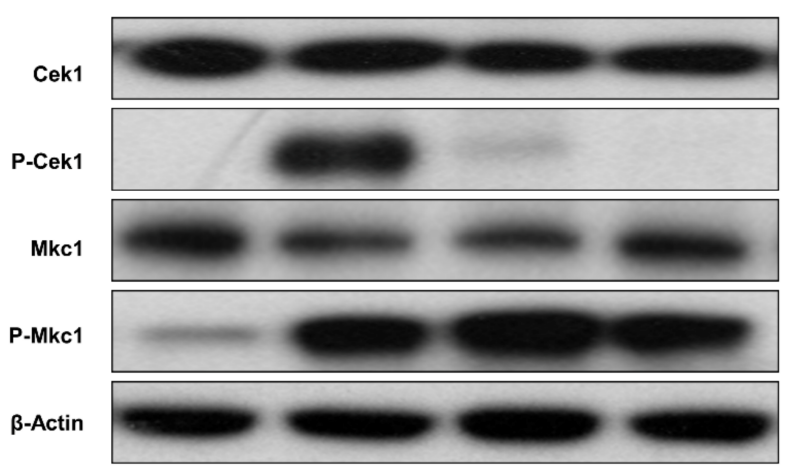

Figure 5. mRNA and protein expression levels of RAS1 and mRNA expression levels of MAPK were reduced by Molecule B and Molecule C treatments. However, the level of P-Mkc1 did not decrease, while that of P-Cek1 did, with these treatments. The BWP17 C. albicans strain was used for western blotting and real-time PCR analyses. (a) Relative mRNA expression levels of RAS1 were determined using real-time PCR. (b) In western blotting, CaRas1 was detected using the anti-Ras10 antibody, and $\beta$-actin was used as a loading control. The quantification graph by Image J software was prepared by normalizing the ratio of each CaRas1 blot to each $\beta$-actin loading control. The relative mRNA expression levels of CEK1 (c), and MKC1 (d) were determined using real-time PCR. (e) Western blotting was performed by detecting Phospho-Mkc1 and Phospho-Cek1 using an antiphospho-p44/42 antibody. Mkc1 and Cek1 were detected using the anti-p44/42 antibody, and $\beta$-actin was used as a loading control. Y, yeast cells; $\mathrm{H}$, hyphae induced cells; HB, hyphae induced cells treated with $8 \mu \mathrm{g} / \mathrm{mL}$ Molecule B; HC, hyphae induced cells treated with $16 \mu \mathrm{g} / \mathrm{mL}$ Molecule C. Each experiment was conducted in triplicate. The data represent the mean and standard deviation of three independent experiments. ${ }^{*} p<0.05,{ }^{* *} p<0.01,{ }^{* * *} p<0.001$ (t-test). 


\section{Discussion}

In this study, we first evaluated the inhibitory activity of 31 carbazole derivatives on the growth of $C$. albicans and their cytotoxicity to mammalian cells. Our results showed that Molecule $\mathrm{B}$ and Molecule $\mathrm{C}$ are appropriate agents for the growth inhibition of C. albicans. In addition, Molecule $B$ and Molecule $C$ were found to be nontoxic to mammalian cells at each tested MIC. We also confirmed the inhibitory effect of Molecule B and Molecule C on the growth of fluconazole- and caspofungin-resistant $C$. albicans strains. Many studies have suggested that the processes of biofilm formation [33] and morphogenesis [44] of C. albicans are closely related to pathogenicity. We found that Molecule B and Molecule $C$ could inhibit the pathogenicity of $C$. albicans by inhibiting morphogenesis and biofilm formation. In addition, as a result of studying the survival rate of candidiasis mice by treatment with Molecule B and Molecule C in the in vivo experiment, it was confirmed that the pathogenicity of $C$. albicans was reduced. Surprisingly, not only candidiasis mice treated with Molecule $B$ and Molecule $C$ via tail vein injection but also mice given Molecule $B$ and Molecule $C$ dissolved in drinking water showed high survival rates. Both mice that drank water containing Molecule B and Molecule $\mathrm{C}$ and mice treated with Molecule $B$ and Molecule $C$ via tail vein injection had very low levels of Candida infection in the kidneys compared to controls. We predict that the results of this in vivo study were due to the inhibitory effect of Molecule B and Molecule C on the morphogenesis of C. albicans. Therefore, Molecule B and Molecule C could be effective candidates for the development of novel antifungal agents.

Fluconazole (azole) and caspofungin (echinocandin), which are commonly used as antifungal agents, target enzymes essential for cell wall ergosterol biosynthesis and the process of fungal cell wall synthesis, respectively. In order to control the growth of $C$. albicans strains resistant to these drugs, novel antifungal agents with different targets than those commonly used are needed. Our results showed that Molecule B and Molecule C regulate the activity of Ume6 and Nrg1, which are involved in the expression of HSGs, as well as disrupting the Ras1/MAPK pathway, which is mainly used for morphogenesis in C. albicans. In addition, it was confirmed that the MAPK pathway signaling components STE11 (MAPKKK), HST7 (MAPKK), and CEK1 (MAPK) were inhibited at the mRNA level by Molecule $B$ and Molecule $C$. The effect of inhibition of biofilm formation even at concentrations lower than the MIC can be attributed to the suppression of the expression of ALS3 and HWP1 by Molecule B and Molecule C. We believe that the inhibition of the expression of ALS3 and HWP1 by Molecule B and Molecule $\mathrm{C}$ at a step corresponding to the surface adhesion step in the biofilm formation process makes biofilm initiation no longer possible. Als3 and Hwp1 have also been reported to play an important role in biofilm formation [40,45]. Given that Molecule B and Molecule C caused a reduction in the Candida infection of the kidneys in the candidiasis mouse model, we can conclude that Molecule B and Molecule $C$ suppressed the pathogenicity of $C$. albicans by inhibiting hyphal formation through the Ras1/MAPK signaling pathway.

The model illustrated in Figure 6 demonstrates how Molecule B and Molecule C regulate filamentous growth in $C$. albicans. Molecule $B$ and Molecule $C$ regulate the 'RAS1 and CEK1'-mediated MAPK pathway (STE11-HST7-CEK1) which is associated with the hyphal cell wall construction and invasive growth. In this study, we introduced Molecule $B$ and Molecule $C$, which reduce the virulence of $C$. albicans by inhibiting morphogenesis via the Ras1/MAPK pathway. Our findings suggest that Molecule $B$ and Molecule $C$ are promising compounds for the development of new antifungal agents for the treatment of systemic candidiasis and possibly, for other fungal diseases. 


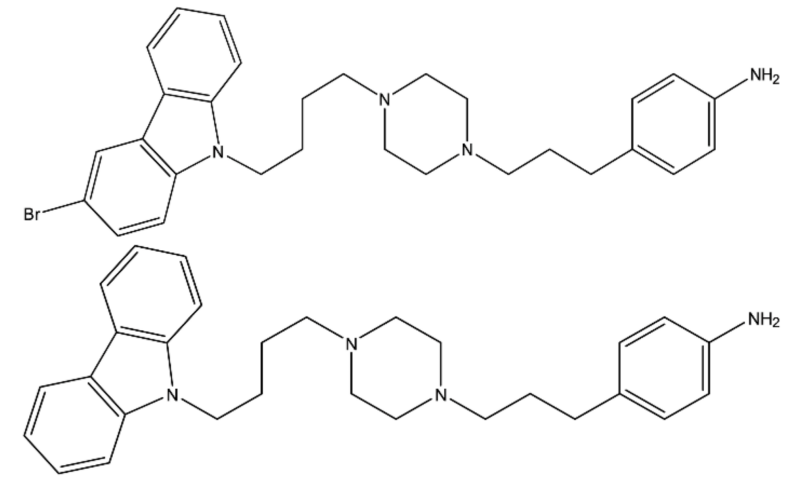

Molecule B and Molecule C

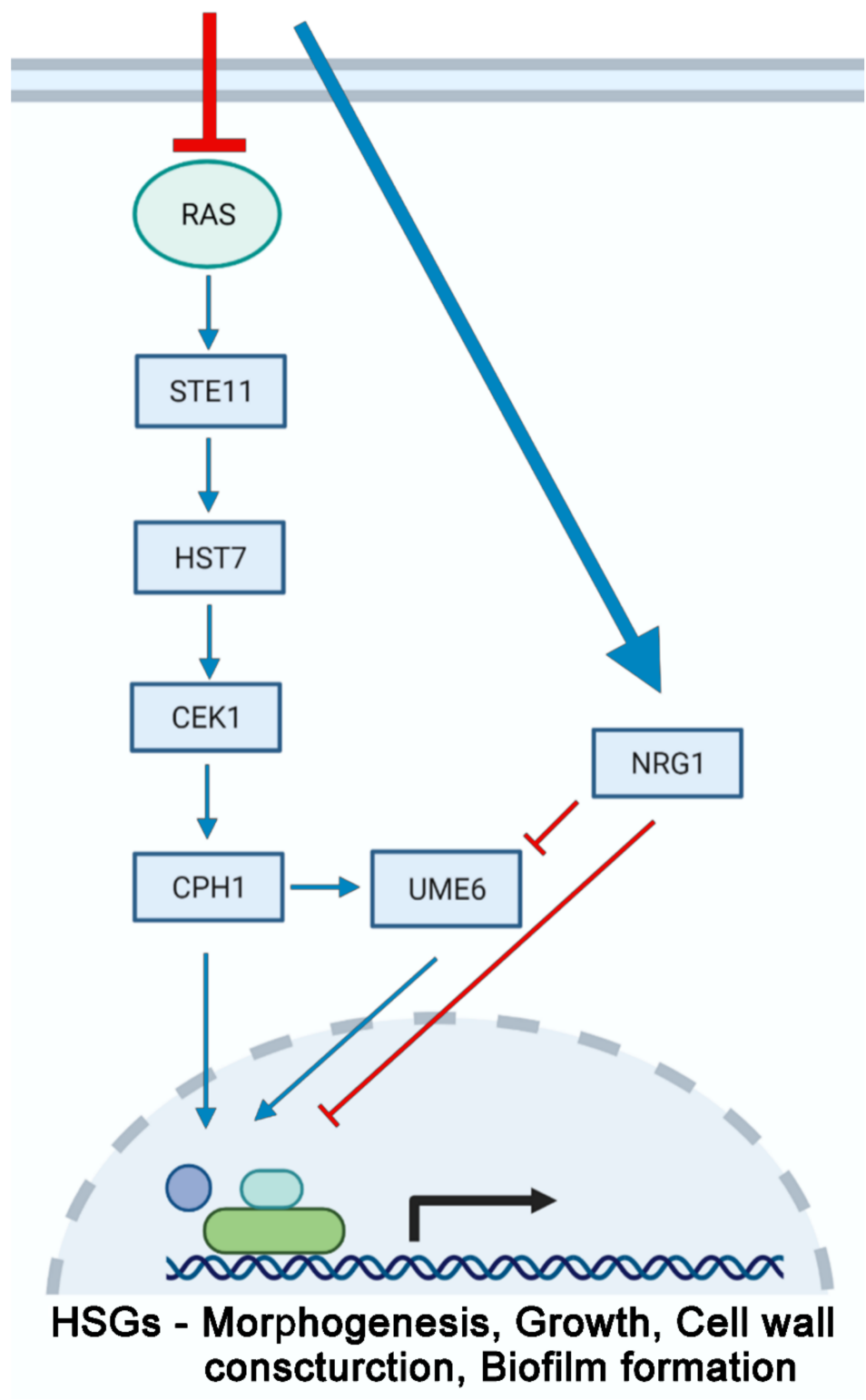

Figure 6. Putative model of virulence inhibition in C. albicans by Molecule B and Molecule C. The inhibitory effects of Molecule B and Molecule $C$ on upstream activator signaling proteins are shown. Molecule B and Molecule C inhibit Ras1 and affect the PAK kinase Cst20, thus affecting the Cek1 MAP kinase cascade, resulting in a decrease in the levels of the transcription factor Cph1. The level of Ume6, which is regulated by the signal of Cph1, also decreases as the amount of Nrg1 increases. 
Supplementary Materials: The following are available online at https: / www.mdpi.com/article/ 10.3390/jof7090688/s1, Figure S1: The cytotoxicity of Molecule B and Molecule C in C. albicans, S. cerevisiae, and mammalian cells, Figure S2: Morphology of the tetO-UME6 strain treated with Molecule B and Molecule $C$ with and without doxycycline, Figure S3: Quantitative RT-PCR analysis of MAPK cascade-related genes in C. albicans, Figure S4: Chemical structures of 31 carbazole derivatives, Table S1: Oligonucleotides used in this study.

Author Contributions: Y.-K.P. designed the study, performed all experiments, analyzed the data, and wrote and edited the manuscript and figures. Y.-K.P. carried out all the experiments including the animal experiments. J.K., J.S. and H.-Y.L. designed and supervised the fabrication of carbazole derivatives. Y.-K.P., H.-D.K. and J.K. contributed to the interpretation of the results. J.K. designed and supervised the work and wrote the manuscript. All authors have read and agreed to the published version of the manuscript.

Funding: This research was funded in part by the National Research Foundation of Korea, NRF2020R1A2C2100803.

Institutional Review Board Statement: This study was performed in accordance with the guidelines of the Institutional Animal Care and Use Committee of Korea University. The protocol and experiments were approved by the Institutional Animal Care and Use Committee of Korea University. The permit number is KUIACUC-2019-0061. All mice used in the experiments were euthanized with minimal suffering.

Informed Consent Statement: Not applicable.

Data Availability Statement: The data presented in this study are available in the main article and Supplementary Materials.

Acknowledgments: This work was supported in part by NRF-2020R1A2C2100803.

Conflicts of Interest: The authors declare no conflict of interest.

\section{References}

1. Al-Hatmi, A.M.S.; Mohsin, J.; Al-Huraizi, A.; Khamis, F. COVID-19 associated invasive candidiasis. J. Infect. 2021, 82, e45-e46. [CrossRef] [PubMed]

2. Govender, N.P.; Todd, J.; Nel, J.; Mer, M.; Karstaedt, A.; Cohen, C.; for GERMS-SA. HIV Infection as Risk Factor for Death among Hospitalized Persons with Candidemia, South Africa, 2012-2017. Emerg. Infect. Dis. 2021, 27, 1607-1615. [CrossRef]

3. San-Juan, R.; Aguado, J.M.; Lumbreras, C.; Fortun, J.; Len, O.; Munoz, P.; Montejo, M.; Moreno, A.; Cordero, E.; Blanes, M.; et al. Universal prophylaxis with fluconazole for the prevention of early invasive fungal infection in low-risk liver transplant recipients. Transplantation 2011, 92, 346-350. [CrossRef] [PubMed]

4. Klein, B.S.; Tebbets, B. Dimorphism and virulence in fungi. Curr. Opin. Microbiol. 2007, 10, 314-319. [CrossRef] [PubMed]

5. Kim, S.W.; Joo, Y.J.; Chun, Y.J.; Park, Y.K.; Kim, J. Cross-talk between Tor1 and Sch9 regulates hyphae-specific genes or ribosomal protein genes in a mutually exclusive manner in Candida albicans. Mol. Microbiol. 2019, 112, 1041-1057. [CrossRef]

6. Gow, N.A.; Brown, A.J.; Odds, F.C. Fungal morphogenesis and host invasion. Curr. Opin. Microbiol. 2002, 5, 366-371. [CrossRef]

7. Sudbery, P.E. Growth of Candida albicans hyphae. Nat. Rev. Microbiol. 2011, 9, 737-748. [CrossRef]

8. Kim, J.; Sudbery, P. Candida albicans, a major human fungal pathogen. J. Microbiol. 2011, 49, 171-177. [CrossRef]

9. Hall, R.A.; De Sordi, L.; Maccallum, D.M.; Topal, H.; Eaton, R.; Bloor, J.W.; Robinson, G.K.; Levin, L.R.; Buck, J.; Wang, Y.; et al. $\mathrm{CO}(2)$ acts as a signalling molecule in populations of the fungal pathogen Candida albicans. PLoS Pathog. 2010, 6, e1001193. [CrossRef]

10. Kohler, J.R.; Fink, G.R. Candida albicans strains heterozygous and homozygous for mutations in mitogen-activated protein kinase signaling components have defects in hyphal development. Proc. Natl. Acad. Sci. USA 1996, 93, 13223-13228. [CrossRef]

11. Feng, Q.; Summers, E.; Guo, B.; Fink, G. Ras signaling is required for serum-induced hyphal differentiation in Candida albicans. J. Bacteriol. 1999, 181, 6339-6346. [CrossRef]

12. Banerjee, M.; Thompson, D.S.; Lazzell, A.; Carlisle, P.L.; Pierce, C.; Monteagudo, C.; Lopez-Ribot, J.L.; Kadosh, D. UME6, a novel filament-specific regulator of Candida albicans hyphal extension and virulence. Mol. Biol. Cell 2008, 19, 1354-1365. [CrossRef]

13. Murad, A.M.; Leng, P.; Straffon, M.; Wishart, J.; Macaskill, S.; MacCallum, D.; Schnell, N.; Talibi, D.; Marechal, D.; Tekaia, F.; et al. NRG1 represses yeast-hypha morphogenesis and hypha-specific gene expression in Candida albicans. EMBO J. 2001, 20, 4742-4752. [CrossRef]

14. Braun, B.R.; Kadosh, D.; Johnson, A.D. NRG1, a repressor of filamentous growth in C.albicans, is down-regulated during filament induction. EMBO J. 2001, 20, 4753-4761. [CrossRef] [PubMed]

15. Hitchcock, C.A. Cytochrome P-450-dependent 14 alpha-sterol demethylase of Candida albicans and its interaction with azole antifungals. Biochem. Soc. Trans. 1991, 19, 782-787. [CrossRef] [PubMed] 
16. Xue, Y.J.; Li, M.Y.; Jin, X.J.; Zheng, C.J.; Piao, H.R. Design, synthesis and evaluation of carbazole derivatives as potential antimicrobial agents. J. Enzym. Inhib. Med. Chem. 2021, 36, 295-306. [CrossRef] [PubMed]

17. Gluszynska, A. Biological potential of carbazole derivatives. Eur. J. Med. Chem. 2015, 94, 405-426. [CrossRef]

18. Lee, H.Y.; Jung, Y.; Kim, W.; Kim, J.H.; Suh, M.S.; Shin, S.K.; Yoon, H.J. Structure-activity relationship studies of the chromosome segregation inhibitor, Incentrom A. Bioorganic Med. Chem. Lett. 2008, 18, 4670-4674. [CrossRef]

19. Kim, S.W.; Park, Y.K.; Joo, Y.J.; Chun, Y.J.; Hwang, J.Y.; Baek, J.H.; Kim, J. Subunits of the vacuolar H+-ATPase complex, Vma4 and Vma10, are essential for virulence and represent potential drug targets in Candida albicans. Fungal Biol. 2019, 123, 709-722. [CrossRef]

20. Jung, Y.; Kim, H.D.; Yang, H.W.; Kim, H.J.; Jang, C.Y.; Kim, J. Modulating cellular balance of Rps3 mono-ubiquitination by both Hel2 E3 ligase and Ubp3 deubiquitinase regulates protein quality control. Exp. Mol. Med. 2017, 49, e390. [CrossRef]

21. Seong, K.M.; Jung, S.O.; Kim, H.D.; Kim, H.J.; Jung, Y.J.; Choi, S.Y.; Kim, J. Yeast ribosomal protein S3 possesses a beta-lyase activity on damaged DNA. FEBS Lett. 2012, 586, 356-361. [CrossRef]

22. Clinical and Laboratory Standards Institute. Reference Method for Broth Dilution Antifungal Susceptibility Testing of Yeasts; Approved Standard-Third Edition; CLSI document M27-A3; Clinical and Laboratory Standards Institute: Wayne, PA, USA, 2008; ISBN 1-56238-666-2.

23. Fonzi, W.A.; Irwin, M.Y. Isogenic strain construction and gene mapping in Candida albicans. Genetics 1993, 134, 717-728. [CrossRef] [PubMed]

24. Wilson, R.B.; Davis, D.; Mitchell, A.P. Rapid hypothesis testing with Candida albicans through gene disruption with short homology regions. J. Bacteriol. 1999, 181, 1868-1874. [CrossRef] [PubMed]

25. White, T.C.; Pfaller, M.A.; Rinaldi, M.G.; Smith, J.; Redding, S.W. Stable azole drug resistance associated with a substrain of Candida albicans from an HIV-infected patient. Oral. Dis. 1997, 3 (Suppl. 1), S102-S109. [CrossRef] [PubMed]

26. Garcia-Effron, G.; Park, S.; Perlin, D.S. Correlating echinocandin MIC and kinetic inhibition of fks1 mutant glucan synthases for Candida albicans: Implications for interpretive breakpoints. Antimicrob. Agents Chemother. 2009, 53, 112-122. [CrossRef] [PubMed]

27. Kim, Y.; Kim, H.D.; Kim, J. Cytoplasmic ribosomal protein S3 (rpS3) plays a pivotal role in mitochondrial DNA damage surveillance. Biochim. Biophys Acta 2013, 1833, 2943-2952. [CrossRef]

28. Kim, T.S.; Kim, H.D.; Park, Y.J.; Kong, E.; Yang, H.W.; Jung, Y.; Kim, Y.; Kim, J. JNK activation induced by ribotoxic stress is initiated from $80 \mathrm{~S}$ monosomes but not polysomes. BMB Rep. 2019, 52, 502-507. [CrossRef]

29. Jung, Y.; Seong, K.M.; Baek, J.H.; Kim, J. Ssb2 is a novel factor in regulating synthesis and degradation of Gcn4 in Saccharomyces cerevisiae. Mol. Microbiol. 2018, 110, 728-740. [CrossRef]

30. Yang, H.W.; Kim, H.D.; Kim, T.S.; Kim, J. Senescent cells differentially translate senescence-related mRNAs via ribosome heterogeneity. J. Gerontol. Ser. A Biol. Sci. Med. Sci. 2019, 74, 1015-1024. [CrossRef]

31. Kong, E.; Kim, H.D.; Kim, J. Deleting key autophagy elongation proteins induces acquirement of tumor-associated phenotypes via ISG15. Cell Death Differ. 2020, 27, 2517-2530. [CrossRef]

32. Joo, Y.J.; Kim, J.H.; Kang, U.B.; Yu, M.H.; Kim, J. Gcn4p-mediated transcriptional repression of ribosomal protein genes under amino-acid starvation. EMBO J. 2011, 30, 859-872. [CrossRef]

33. McCall, A.D.; Pathirana, R.U.; Prabhakar, A.; Cullen, P.J.; Edgerton, M. Candida albicans biofilm development is governed by cooperative attachment and adhesion maintenance proteins. NPJ Biofilms Microbiomes 2019, 5, 21. [CrossRef]

34. Kim, S.W.; Joo, Y.J.; Kim, J. Asc1p, a ribosomal protein, plays a pivotal role in cellular adhesion and virulence in Candida albicans. J. Microbiol. 2010, 48, 842-848. [CrossRef]

35. Navarathna, D.H.; Nickerson, K.W.; Duhamel, G.E.; Jerrels, T.R.; Petro, T.M. Exogenous farnesol interferes with the normal progression of cytokine expression during candidiasis in a mouse model. Infect. Immun. 2007, 75, 4006-4011. [CrossRef] [PubMed]

36. Hoyer, L.L. The ALS gene family of Candida albicans. Trends Microbiol. 2001, 9, 176-180. [CrossRef]

37. Moyes, D.L.; Wilson, D.; Richardson, J.P.; Mogavero, S.; Tang, S.X.; Wernecke, J.; Hofs, S.; Gratacap, R.L.; Robbins, J.; Runglall, M.; et al. Candidalysin is a fungal peptide toxin critical for mucosal infection. Nature 2016, 532, 64-68. [CrossRef] [PubMed]

38. Finkel, J.S.; Mitchell, A.P. Genetic control of Candida albicans biofilm development. Nat. Rev. Microbiol. 2011, 9, 109-118. [CrossRef]

39. Han, T.L.; Cannon, R.D.; Villas-Boas, S.G. The metabolic basis of Candida albicans morphogenesis and quorum sensing. Fungal Genet. Biol. 2011, 48, 747-763. [CrossRef]

40. Sharkey, L.L.; McNemar, M.D.; Saporito-Irwin, S.M.; Sypherd, P.S.; Fonzi, W.A. HWP1 functions in the morphological development of Candida albicans downstream of EFG1, TUP1, and RBF1. J. Bacteriol. 1999, 181, 5273-5279. [CrossRef]

41. Carlisle, P.L.; Kadosh, D. Candida albicans Ume6, a filament-specific transcriptional regulator, directs hyphal growth via a pathway involving Hgc1 cyclin-related protein. Eukaryot. Cell 2010, 9, 1320-1328. [CrossRef]

42. Park, Y.N.; Morschhauser, J. Tetracycline-inducible gene expression and gene deletion in Candida albicans. Eukaryot. Cell 2005, 4, 1328-1342. [CrossRef] 
43. Berman, J.; Sudbery, P.E. Candida Albicans: A molecular revolution built on lessons from budding yeast. Nat. Rev. Genet. 2002, 3, 918-930. [CrossRef] [PubMed]

44. Lo, H.J.; Kohler, J.R.; DiDomenico, B.; Loebenberg, D.; Cacciapuoti, A.; Fink, G.R. Nonfilamentous C. albicans mutants are avirulent. Cell 1997, 90, 939-949. [CrossRef]

45. Zhao, X.; Daniels, K.J.; Oh, S.H.; Green, C.B.; Yeater, K.M.; Soll, D.R.; Hoyer, L.L. Candida albicans Als3p is required for wild-type biofilm formation on silicone elastomer surfaces. Microbiology 2006, 152, 2287-2299. [CrossRef] [PubMed] 